\title{
Analisis Laporan Keuangan Menggunakan Rasio Profitabilitas dan Rasio Likuiditas pada CV Dandi Brothers Kota Bengkulu
}

\author{
Andini Utari Putri ${ }^{1)}$ \\ ${ }^{1)}$ Program Studi Akuntansi, Universitas Indo Global Mandiri, Palembang \\ Email: andini@uigm.ac.id ${ }^{l}$
}

\begin{abstract}
ABSTRAK
Penelitian ini bertujuan untuk menganalisis laporan keuangan menggunakan rasio profitabilitas dan Rasio Likuiditas Pada CV Dandi Brothers di Kota Bengkulu. Penelitian ini menggunakan data sekunder berupa laporan keuangan dari CV Dandi Brothers pada tahun 2018 sampai dengan 2019. Laporan keuangan tersebut dianalisis menggunakan rasio profitabilitas dan rasio likuiditas. Hasil penelitian ini menunjukkan bahwa CV Dandi Brother mengalam peningkatan dari tahun 2018 sampai dengan 2019. Peningkatan itupun juga terlihat dari aset yang dimiliki mengalami penambahan dari tahun ke tahun dan $C V$ Dandi Brother memiliki liabilitas yang tidak begitu besar jika dibandingkan dengan aktiva dan persediaan yang dimiliki.
\end{abstract}

Kata Kunci: Laporan Keuangan, Rasio Profitabilitas, Rasio Likuiditas

\section{Pendahuluan}

Banyak cara yang dapat dilakukan dalam proses peninterpretasian informasi akuntansi yang dapat dikatakan sebagai informasi yang andal dan relatif ataupun dapat dikatakan sebagai informasi akuntansi yang akuntabilitas. Dimana menjelaskan hubungan tertentu antara angka yang satu dengan angka yang lain dari suatu laporan keuangan dimaksudkan untuk menilai risiko dan peluang pada masa yang akan datang. Pengukuran dan hubungan satu pos dengan pos lain dalam laporan keuangan yang tampak dalam rasio-rasio keuangan dapat memberikan kesimpulan berarti dalam penentuan tingkat kesehatan keuangan suatu perusahaan. Tetapi bila hanya memperhatikan suatu alat rasio saja tidaklah cukup sehingga harus dilakukan pula analisis persainganpersaingan yang sedang dihadapi oleh manajemen perusahaan dalam industri yang lebih luas dan dikombinasikan dengan analisis kualitatif atas bisnis dan industri manufaktur, analisis kualitatif, serta penelitianpenelitian industry (Elia, 2017).

Analisis laporan keuangan merupakan salah satu bentuk yang dapat digunakan untuk menilai kinerja perusahaan apakah perusahaan dalam kondisi yang baik atau tidak. Untuk mengetahui kondisi tersebut dapat dilakukan berbagai analisis dan salah satunya yaitu analisis rasio. Analisis rasio keuangan membutuhkan laporan keuangan sedikitnya 2 (dua) tahun terakhir dari berjalannya perusahaan agar dapat dibandingkan. Analisis rasio keuangan akan dapat mengetahui seperti apa kondisi kinerja keuangan perusahaan. Analisis rasio dapat diklasifiksikan dalam berbagai jenis, diantaranya yaitu rasio likuiditas, solvabilitas, aktivitas, dan profitabilitas. Tingkat likuiditas akan menunjukan sejauh mana perusahaan mampu memenuhi kewajiban jangka pendeknya dengan jaminan harta lancar yang dimiliki. Tingkat solvabilitas, akan menunjukan sejauh mana kemampuan perusahaan dalam memenuhi semua kewajiban dengan jaminan harta yang dimiliki. Tingkat aktivitas, mengukur efektivitas suatu perusahaan dalam menggunakan aktiva yang dimilikinya. Dan tingkat profitabilitas, menunjukan sejauh mana perusahaan dapat mampu menghasilkan laba dengan modal yang ada (Maith, 2013: 1 Dalam Tanor, dkk, 2015).

Rasio Keuangan atau financial ratio merupakan alat analisis keuangan perusahaan untuk menilai kinerja suatu perusahaan berdasarkan perbandingan data keuangan yang terdapat pada pos laporan keuangan (neraca, laporan laba/rugi laporan aliran kas). Ratio menggambarkan suatu hubungan atau perimbangan (Mathematical relationship) antara suatu jumlah tertentu dengan jumlah yang lain. Analisis rasio dapat digunakan untuk membimbing investor dan kreditor untuk membuat keputusan atau pertimbangan tentang pencapaian perusahaan dan prospek pada masa datang (Elia, 2017).

Rasio likuditas berfungsi untuk menunjukkan atau mengukur kemampuan perusahaan dalam memenuhi kewajiban yang sudah jatuh tempo, baik kewajiban kepada pihak luar perusahaan (likuiditas badan usaha) maupun di dalam perusahaan (likuiditas perusahaan) (Romli, Ferita, \& Permata, 2016). Rasio likuiditas ini terdiri dari:

a) Current Ratio (Rasio Lancar)

Adalah rasio yang membandingkan aktiva lancar dengan utang lancar. Aktiva lancar meliputi kas, bank, surat-surat berharga, piutang, persediaan, biaya dibayar di muka, pendapatan yang masih harus diterima, dan pinjaman yang diberikan. Sedangkan utang lancar (utang jangka pendek) meliputi utang dagang, utang bank, utang gaji, utang pajak, utang dividen, dan utang lainnya yang harus segera dibayar. Dalam praktiknya, rasio lancar dengan standar 200\% sudah dianggap cukup baik atau memuaskan bagi perusahaan (Kasmir, 2014: 135 
dalam Trianto, 2017). Semakin besar perbandingan aktiva lancar dengan utang lancar semakin tinggi kemampuan perusahaan menutupi kewajiban jangka pendeknya. Rasio ini dapat dibuat dalam bentuk berapa kali atau dalam bentuk persentasi. Apabila rasio lancar ini $1: 1$ atau $100 \%$ ini berarti bahwa aktiva lancar dapat menutupi semua utang lancar. Rasio lancar yang lebih aman adalah jika berada di atas 1 atau di atas $100 \%$. Artinya aktiva lancar harus jauh di atas jumlah utang lancar (Trianto, 2017),

b) Quick Ratio (Rasio Cepat)

Rasio cepat merupakan rasio yang menunjukkan kemampuan perusahaan memenuhi (membayar) kewajiban atau utang lancar (utang jangka pendek) dengan aktiva lancar tanpa memperhitungkan nilai persediaan (inventory), artinya nilai persediaan kita abaikan, dengan cara dikurangi dari nilai total aktiva lancar. Semakin besar rasio ini semakin baik (Kasmir, 2014 dalam Trianto, 2017).

Profitabilitas merupakan hasil akhir bersih dari berbagai kebijakan dan keputusan dimana rasio ini digunakan sebagai alat pengukur atas kemampuan perusahaan untuk memperoleh keuntungan dari setiap rupiah penjualan yang dihasilkan (Widarjo \& Setiawan, 2009 Dalam Fernos, 2017). Sehingga hasil rasio profitabilitas dapat dijadikan gambaran tentang efektivitas kinerja bank ditinjau dari laba bersih yang diperoleh dibandingkan dengan biaya pendapatannya. Profitabilitas merupakan faktor yang seharusnya mendapat perhatian penting karena untuk dapat melangsungkan hidupnya, suatu bank harus Analisis Rasio Profitabilitas berada dalam keadaan yang menguntungkan (profitable). Laba merupakan salah satu indikator kinerja suatu perusahaan. Untuk memperoleh laba, perusahaan harus melakukan kegiatan operasional. Kegiatan operasional ini dapat terlaksana jika perusahaan mempunyai sumber daya. Sumber daya perusahaan tercantum didalam neraca (Meriewaty, D \& Setyani, 2005 dalam Fernos, 2017).

Melalui rasio profitabilitas tersebut dapat dilihat seberapa efektif dan efisiennya manajemen perusahaan untuk memaksimalkan nilai perusahaan. pengelolaan aset atau sumber daya perusahaan yang dilakukan oleh manajemen perusahaan untuk memaksimalkan nilai perusahaan. Saat ini teknologi komunikasi dan informasi tidak hanya menjadi instrumen peningkatan efektifitas dan efisiensi bisnis tetapi juga telah menjadi area bisnis yang menjanjikan, yang banyak diperebutkan pelaku usaha karena potensi luar biasa yang dikandungnya. Berbagai produk teknologi komunikasi baru yang lebih nyaman dan canggih merupakan strategi yang sangat penting bagi perusahaan yang bergerak dalam bidang komunikasi untuk dapat merebut pasar.

Tujuan akhirnya adalah untuk mencapai profitabilitas yang maksimal, yang dapat diketahui melalui kinerja keuangan perusahaan. Salah satu rasio untuk menilai prestasi perusahaan atau kinerja keuangan perusahaan adalah rasio profitabilitas yang menghubungkan dua data keuangan yang satu dengan yang lainnya. Rasio profitabilitas akan memberikan jawaban akhir tentang efektivitas manajemen perusahaan dan rasio ini memberikan gambaran tentang efektivitas manajemen pengelolaan perusahaan. Salah satu rasio bentuk dari rasio profitabilitas yang dimaksudkan dapat mengukur kemampuan perusahaan dengan keseluruhan dana yang ditanamkan dalam aktiva yang digunakan untuk operasi perusahaan dalam menghasilkan keuntungan adalah rasio return on investment (ROI), di mana rasio ini merupakan teknik analis yang lazim digunakan oleh pimpinan perusahaan untuk mengukur efektifitas operasional perusahaan secara menyeluruh (komprehensif) Munawir, (2007:89); Saefullah, dkk, (2018).

CV Dandy Brothers merupakan perusahan yang bergerak dalam bidang pelayanan jasa yang meliputi, penyewaan tenda, alat catering, pelaminan beserta kelengkapan baik dari baju pengantin sampai aksesoris sunting dan lain - lain untuk keperluan pernikahan ataupun lainnya. CV Dandy Brothers bermula dari usaha kecil biasa yang hanya menawarkan jasa berupa penyewaan tenda. Semakin berjalannya waktum CV Dandy Brothers berkembang yang awalnya hanya beberapa unit lokal tenda hingga saat ini memiliki ratusan lokal tenda yang dapat disewakan kepada konsumen. Pada saat inilah entitas tersebut membuka lembaran baru dengan mendaftarkan usahanya guna mendapatkan kemudahan dan melakukan kewajiban sebagai warga negara Indonesia. Hingga saat ini entitas tersebut berkembang cukup pesat dengan melebarkan sayapnya menjadi Dandy Decoration yaitu buka saja mencakup penyewaan tenda, tetapi juga memberikan pelayanan jasa dengan menyewakan dan melayani calon pengantin berupa pelaminan dan juga baju - baju pengantin hingga aksesoris yang diperlukan dalam acara - acara tersebut. Dan juga Dandy Brothers menyewakan keperluan kegiatan - kegiatan diluar dari acara pernikahan.

Dengan semakin luasnya cakupan yang bermula hanya usaha biasa hingga menjadi CV Dandi Brothers tersebut, tentu diperlukannya laporan keuangan yang akuntabilitas dimana dengan menilai laporan kinerja keuangan dengan menggunakan rasio profitabilitas sebagai indikator kinerja keuangan.

Berdasarkan uraian latar belakang penelitian yang telah dijelaskan maka rumusan masalah dalam penelitian ini adalah bagaimanakah laporan keuangan diukur dengan menggunakan rasio profitabilitas dan rasio likuiditas pada CV Dandi Brothers?

Sesuai dengan permasalahan yang akan diteliti, maka tujuan penelitian adalah untuk mengetahui laporan keuangan diukur dengan menggunakan rasio profitabilitas dan rasio likuiditas pada CV Dandi Brothers. 


\section{Landasan Teori \\ Laporan Keuangan}

PSAK No. 1 tentang Penyajian Laporan Keuangan (revisi 2009) menyatakan laporan keuangan adalah suatu penyajian terstruktur dari posisi keuangan dan kinerja keuangan suatu entitas. Jadi laporan keuangan merupakan salah satu informasi yang sangat penting dalam menilai perkembangan perusahaan. Laporan keuangan dapat digunakan untuk menilai prestasi yang dicapai perusahaan pada saat lampau, sekarang dan rencana pada waktu yang akan datang. Kasmir (2008:7) ; Maith (2013) laporan keuangan adalah laporan yang menunjukkan kondisi keuangan perusahaan pada saat ini atau dalam suatu periode tertentu. Susilo (2009:10) ; Maith (2013 menyatakan bahwa laporan keuangan adalah hasil akhir dari proses akuntansi yang memuat informasi-informasi dan memberikan keterangan-keterangan mengenai data ekonomi perusahaan yang terdiri dari daftar-daftar yang menunjukan posisi keuangan dan hasil kegiatan perusahaan untuk satu periode yang meliputi neraca, laporan laba rugi dan laporan perubahan keuangan.

Tujuan laporan keuangan yaitu untuk menyediakan informasi yang berkaitan dengan posisi keuangan, prestasi (hasil usaha) perusahaan serta perubahan posisi keuangan suatu perusahaan yang bermanfaat bagi pemakai dalam pengambilan keputusan ekonomi. PSAK No. 1 tentang Penyajian Laporan Keuangan (revisi 2009) menyatakan tujuan laporan keuangan adalah memberikan informasi mengenai posisi keuangan, kinerja keuangan, dan arus kas entitas yang bermanfaat bagi sebagian besar kalangan pengguna laporan dalam pembuatan keputusan ekonomi (Maith, 2013).

\section{Jenis Laporan Keuangan}

Jenis laporan keuangan utama dan pendukung laporan keuangan terdiri atas (Harahap, 2015;106):

a. Daftar Neraca yang menggambarkan posisi keuangan perusahaan pada satu tanggal tertentu.

b. Perhitungan laba/rugi yang menggambarkan jumlah hasil, biaya, dan laba/rugi perusahaan pada suatu periode tertentu.

c. Laporan dan sumber penggunaan dana, disini dimuat sumber dan pengeluaran perusahaan selama periode tertentu.

d. Laporan arus kas, disini digambarkan sumber dan penggunaan kas dalam suatu periode.

e. Laporan harga pokok produksi yang menggambarkan berapa dan unsur apa yang diperhitungkan dalam harga pokok produksi suatu barang.

f. Laporan laba ditahan, menjelaskan posisi laba ditahan yang tidak dibagikan kepada pemilik saham.

g. Laporan perubahan modal, menjelaskan perubahan posisi modal baik saham dalam Perseroan Terbatas atau modal dalam perusahaan perseroan.

\section{Analisa Laporan Keuangan}

Analisis Laporan Keuangan adalah menguraikan pos-pos laporan keuangan menjadi unit informasi yang lebih kecil dan melihat hubungannya yang bersifat signifikan atau mempunyai makna antara satu dengan yang lain, baik antara data kuantitatif maupun data non kuantitatif." Agar laporan keuangan menjadi lebih berarti sehingga dapat dipahami dan dimengerti oleh berbagai pihak, perlu dilakukan analisa laporan keuangan. Tujuan utama dari analisis laporan keuangan adalah agar dapat mengetahui posisi keuangan perusahaan saat ini (Harahap, 2010:190).

Jadi dengan mengetahui posisi keuangan, setelah dilakukan analisis laporan keuangan secara mendalam, akan terlihat apakah perusahaan dapat mencapai target yang telah direncanakan sebelumnya atau tidak. Hasil analisis laporan keuangan juga akan memberikan informasi tentang kelemahan dan kekuatan yang dimiliki perusahaan. Dengan mengetahui kelemahaan ini, manajemen akan dapat memperbaiki atau menutupi kelemahan tersebut. Kemudian, kekuatan yang dimiliki perusahaan harus dipertahankan atau bahkan ditingkatkan. Dengan adanya kelemahan dan kekuatan yang dimiliki akan tergambar kinerja manajemen selama ini. (Kasmir, 2014:66).

\section{Analisa Rasio Keuangan}

Analisis Rasio Keuangan Rasio keuangan merupakan suatu perhitungan rasio dengan menggunakan laporan keuangan yang berfungsi sebagai alat ukur dalam menilai kondisi keuangan dan kinerja perusahaan. Rasio keuangan adalah angka yang diperoleh dari hasil perbandingan antara satu pos laporan keuangan dengan pos lainnya yang mempunyai hubungan yang relevan dan signifikan (Hery, 2015).

Dari pengertian diatas dapat disimpulkan bahwa analisis rasio keuangan adalah suatu metode analisa yang membandingkan pos laporan keuangan dengan pos lainnya untuk menilai kinerja perusahaan. Tujuan dari rasio keuangan adalah membantu manajer dalam memahami apa yang perlu dilakukan perusahaan sehubungan dengan informasi yang berasal dari keuangan yang sifatnya terbatas. Dengan menggunakan rasio-rasio tertentu manajer akan memperoleh suatu informasi tentang kekuatan dan kelemahan perusahaan dibidang keuangan. Dari informasi tersebut, manajer dapat membuat keputusan-keputusan penting di masa yang akan datang (Trianto, 2017).

\section{Rasio Likuiditas}

Rasio likuiditas menurut Fred Weston dalam Kasmir (2016), "merupakan rasio yang menggambarkan kemampuan perusahaan dalam memenuhi kewajiban jangka pendek". Fungsi lain dari rasio likuiditas adalah untuk menunjukkan atau mengukur kemampuan perusahaan dalam memenuhi kewajibannya yang jatuh 
tempo, baik kewajiban kepada pihak luar perusahaan (likuiditas badan usaha) maupun di dalam perusahaan (likuiditas perusahaan).

\section{Rasio Profitabilitas}

Menurut Kasmir (2016), bahwa: "rasio profitabilitas merupakan rasio yang digunakan untuk menilai kemampuan perusahaan dalam mencari keuntungan". Rasio ini juga memberikan unkuran tingkat efektivitas manajemen suatu perusahaan (Armereo, 2015; Purnamasari, 2016; Halin, 2016; Utari, Gustini, \& Permata, 2018; Sayadi, 2019). Hal ini ditunjukkan oleh laba yang dihasilkan dari penjualan dan pendapatan investasi.

\section{Metodologi Penelitian}

Dalam penelitian ini dilakukan di CV Dandi Brothers Kota Bengkulu yang bergerak dalam bidang pelayanan jasa menyediakan penyewaan pelaminan, tenda untuk kegiatan dan juga pesta pernikahan. CV Dandi Brother juga menyediakan peralatan catering. Jenis dan Sumber data dalam penelitian ini adalah data sekunder dimana untuk melihat laporan keuangan periode 2018 dan 2019 dengan menggunakan rasio profitabilitas dan rasio likuiditas dengan membandingkan 2 tahun tersebut. Teknik analisa data yang digunakan dalam penelitian ini adalah kualitatif dengan menganalisa hasil dari perhitungan rasio profitabilitas dan rasio likuitditas.

\section{Analisis Penelitian}

Rasio Profitabilitas Tahun 2018

a. Gross Profit Margin

$\frac{\text { Penjualan }- \text { Harga Pokok Penjualan }}{\text { Penjualan }}$

$\frac{\text { Rp.300.000.000-Rp 200.000.000 }}{300.000 .000} \times 100 \%$

$=33 \%$

b. Net Profit Margin

Laba Setelah Pajak

Penjualan

$\frac{\text { Rp. } 70.000 .000}{\operatorname{Rp~} 300.000 .000} \times 100 \%$

$=2,3 \%$

c. Return on Investmen/Return on Total Assets

(ROI)

$\frac{\text { Laba Setelah Pajak (EAT) }}{\text { Total Aktiva }} \times 100 \%$

$\frac{\text { Rp.70.000.000 }}{\text { Rp } 1.200 .000 .000} \times 100 \%$

$=6 \%$ d. Rasio on Net Worth (Returen on Equity) ROE $\frac{\text { Laba Setelah Pajak (EAT) }}{\text { Modal Sendiri }} \times 100 \%$

$$
\begin{aligned}
& \frac{\text { Rp. } 70.000 .000}{\mathrm{Rp} 350.000 .000} \times 100 \% \\
= & 20 \%
\end{aligned}
$$

\section{Rasio Profitabilitas Tahun 2019}

a. Gross Profit Margin

$$
\begin{aligned}
& \frac{\text { Penjualan }- \text { Harga Pokok Penjualan }}{\text { Penjualan }} \\
& \frac{\text { Rp.480.000.000-Rp 220.000.000 }}{480.000 .000} \times 100 \% \\
& =54 \%
\end{aligned}
$$

b. Net Profit Margin

Laba Setelah Pajak

$$
\text { Penjualan }
$$

$$
\begin{aligned}
& \frac{\text { Rp. } 180.000 .000}{\operatorname{Rp~} 480.000 .000} \times 100 \% \\
& =37 \% \\
& =2,3 \%
\end{aligned}
$$

c. Return on Investmen/Return on Total Assets (ROI)

$$
\begin{aligned}
& \frac{\text { Laba Setelah Pajak (EAT) }}{\text { Total Aktiva }} \times 100 \% \\
& \frac{\text { Rp. } 180.000 .000}{\text { Rp } 1.350 .000 .000} \times 100 \% \\
& =13 \%
\end{aligned}
$$

d. Rasio on Net Worth (Returen on Equity) ROE $\frac{\text { Laba Setelah Pajak (EAT) }}{\text { Modal Sendiri }} \times 100 \%$

$$
\begin{aligned}
& \frac{\mathrm{Rp} .180 .000 .000}{\mathrm{Rp} 460.000 .000} \times 100 \% \\
= & 39 \%
\end{aligned}
$$

\section{Rasio Likuiditas Tahun 2018}

a. Current Ratio

$\frac{\text { Aktiva Lancar }}{\text { Utang Lancar }} \times 100 \%$

$\frac{400.000 .000}{20.000 .000} \times 100 \%$

$$
=20 \%
$$

b. Quick Ratio

$$
\begin{aligned}
& \frac{\text { Aktiva Lancar - Persediaan }}{\text { Utang Lancar }} \\
& \frac{400.000 .000-250.000 .000}{20.000 .000} \times 100 \% \\
& =7,5 \%
\end{aligned}
$$


Rasio Likuiditas Tahun 2019

a. Current Ratio

$\frac{\text { Aktiva Lancar }}{\text { Utang Lancar }} \times 100 \%$

$\frac{520.000 .000}{13.000 .000} \times 100 \%$

$=40 \%$

b. Quick Ratio

Aktiva Lancar - Persediaan

Utang Lancar

$\frac{520.000 .000-300.000 .000}{13.000 .000} \times 100 \%$

$=17 \%$

\section{Pembahasan \\ Rasio Profitabilitas}

Rasio profitabilitas mengukur kemampuan perusahaan untuk menghasil-kan keuntungan atas pemanfaatan sumber daya yang dimilikinya. Hasil pengukuran profitabilitas didasarkan pada gross profit margin, net profit margin, Return on Investmen / Return on Total Assets (ROI) dan Rasio on Net Worth (Return on Equity atau ROE) menunjukkan kondisi profitabilitas perusahaan selama tahun 2014-2015 terus mengalami peningkatan, didasarkan atas besaran prosentase darikeempat rasio yang digunakan. Hasil ini menunjukkan bahwa kemampuan perusahaan untuk memperoleh keuntungan, baik berupa laba kotor (gross profit) maupun laba bersih (net profit) selama periode duatahun tersebut mengalami peningkatan. Nilai ROI menunjukkan perbandingan laba bersih setelah pajak terhadap total aktiva terus menaik, yang berarti kemampuan perusahaan mengelola sumber daya yangdimiliki dalam tujuan mempertinggi keuntungan yang diperoleh terbukti semakin meningkat (Elia, 2017).

Gross Profit Margin (GPM), adalah rasio untuk mengukur kemampuan perusahaan dalam mendapatkan laba kotor dari penjualan. Hasil dari pada GPM 2018 sebesar 33\% sedangkan pada tahun 2019 meningkat menjadi $54 \%$. Artinya meningkat sebanyak $21 \%$. Dengan demikian CV Dandi Brothers meningkatkan penjualan jasa yang disediakan oleh CV Dandi Brothers dalam memperoleh keuntungan atau laba.

Net Profit Margin (NPM) ialah untuk mengukur kemampuan perusahaan dalam mendapatkan laba bersih dari penjualan. NPM CV Dandi Brother pada tahun 2018 sebesar 2,3\%. Sedangkan pada tahun 2019 meningkat menjadi $3,7 \%$. Artinya dari tahun 2018 sampai dengan tahun 2019 meningkat sebanyak 1,7\%. Dengan demikian CV Dandi Brothers meningkatkan kinerja perusahaan guna nantinya mendapatkan laba neto. Hal ini juga berkaitan dengan hasil penjualan atau pun pelayanan jasa yang telah dilakukan dan hasil dari CV Dandi Brothers.

Return On Investment (ROI) ialah rasio untuk mengukur kemampuan modal yang mengukur kemampuan modal yang diinvestasikan dalam keseluruhan aktiva untuk menghasilkan pendapatan bersih. ROI CV. Dandi Brothers pada tahun 2018 sebesar 6\% sedangkan pada tahun 2019 meningkat sebesar 13\%. Artinya dalam hal ini CV Dandi Brothers mengalami peningkatan sebesar 7\%. Dimana CV. Dandi Brothers mengalami peningkatan atas kinerja dari $\mathrm{CV}$. Dandi Brothers. Dalam hal ini penggunaan atas aset baik aset tetap ataupun aset lancar mengalami laba dengan peningkatan laba tersebut.

Return on Equity (ROE) ialah rasio untuk mengukur kemampuan equity untuk menghasilkan pendapatan bersih. ROE dari CV. Dandi Brothers pada tahun 2018 sebesar 20\% meningkat sebesar 39\%. Artinya meningkat sebesar 19\%. Dengan kata lain, CV, Dandi Brothers mengalami peningkatan pendapatan bersih dari tahun 2018 sampai tahun 2019.

\section{Rasio Likuiditas}

Elia, (2017) Rasio likuiditas dimaksudkan untuk mengukur kemampuan perusahaan dalam memenuhi kewajiban jangka pendek. Hasil pengukuran likuiditas didasarkan pada current ratio, danacid test ratio (quick Ratio).

Current Ratio merupakan rasio untuk mengukur kemampuan perusahaan dalam membayar kewajiban finansial jangka pendek dengan menggunakan aktiva lancar (Elia, 2018). Dari hasil perhitungan current ratio $\mathrm{CV}$. Dandi Brothers menunjukkan adanya peningkatan terlihat dari tahun 2018 sebesar $20 \%$ sedangkan di tahun 2019 meningkat menjadi 40\%. Artinya dengan adanya peningkatan sebesar $20 \%$ mempunyai kemampuan untuk menutupi utang dengan aktiva lancar yang dimiliki oleh CV. Dandi Brothers dan mempunyai kemampuan dalam membayar kewajiban ataupun liabilitas yang dimiliki oleh CV. Dandi Brothers.

Quick ratio untuk mengukur kemampuan perusahaan dalam membayar kewajiban finansial jangka pendek dengan mengunakan aktiva lancar yang lebih likuid (Liquid Assets) (Wild, 2005; Elia 2017). Dalam perhitungan ini dapat dilihat pada tahun 2018 quick ratio sebesar 7,5\% sedangkan pada tahun 2019 sebesar 17\%. Artiya CV. Dandi Brother mengalami peningkatan sebesar $9,5 \%$. Dimana dengan peningkatan ini dapat dikatakan bahwa CV. Dandi Brother memiliki kemampuan untuk membayarkan kewajiban atau utang lancarnya dengan aset yang dimiliki oleh entitas.

\section{Kesimpulan dan Saran}

Dalam analisis laporan keuangan menggunakan rasio profitabilitas dan rasio likuiditas dapat dilihat bahwa CV Dandi Brother mengalam peningkatan dari tahun 2018 sampai dengan 2019. Peningkatan itupun juga terlihat dari aset yang dimiliki mengalami penambahan dari tahun ke tahun dan CV Dandi Brother memiliki liabilitas yang tidak 
begitu besar jika dibandingkan dengan aktiva dan persediaan yang dimiliki.

Dalam penelitian mengenai rasio profitabilitas dan rasio likuiditas yang dilakukan oleh peneliti pada $\mathrm{CV}$. Dandi Brother Kota Bengkulu. Peneliti memberikan saran kepada peneliti berikutnya untuk menambahkan rasio rasio keuangan lainnya agar cakupan penelitian dapat menjadi lebih luas.

\section{Daftar Pustaka}

Armereo, C. (2015). Analisis Faktor-Faktor yang Mempengaruhi Profitabilitas Bank Syariah yang Terdaftar di Bursa Efek Indonesia Indonesia. Jurnal Ilmiah Ekonomi Global Masa Kini, 6(2), 48-56.

Dwi, Kurnia R, Ode, La S. Analisis Laporan Keuangan Dalam Mengukur Kinerja Perusahan Pada Pt. Ricky Kurniawan Kertapersada (Makin Group) Jambi. $J$ Valuta. 2016;2(2):190-207.

Elia N. Analisis Kinerja Keuangan Pada Cv. Alif Mahardika Putra Di Sangatta. Ekonomia. 2017;6(1):203-211.

Fernos J. Analisis Rasio Profitabilitas Untuk Mengukur Kinerja (Studi Kasus Pada PT. Bank Pembangunan Daerah Provinsi Sumatera Barat). $J$ Pundi. 2017;1(2):107-118. doi:10.31575/jp.v1i2.25

Halin, H. (2016). Pengaruh Rasio Lancar Dan Rasio Hutang Terhadap Profitabilitas Pada Industri Telekomunikasi Yang Listing Di Bursa Efek Indonesia. Jurnal Ilmiah Ekonomi Global Masa Kini, 7(1), 49-54.

Lastria O, John F. Analisa Laporan Keuangan Berdasarkan Tingkat Rentabilitas Bank Pekreditan Rakyat (BPR) Batang Palangki. Ina RXIV. Published online 2019:1-12.

Meiriewaty D, Setyani AY. Analisis Rasio Keuangan Terhadap Perubahan Kinerja Pada Perusahaan di Industri FOOD dan BEVERAGES Yang Terdaftar di BEJ. $J$ dan Pros SNA - Simp Nas Akunt. 2005;8(1):277-287. doi:10.1016/j.aca.2004.09.091

Lastria O, John F. Analisa Laporan Keuangan Berdasarkan Tingkat Rentabilitas Bank Pekreditan Rakyat (BPR) Batang Palangki. Ina RXIV. Published online 2019:1-12.

Purnamasari, E. D. (2017). Analisis Pengaruh Laverage terhadap Profitabilitas Perusahaan yang Termasuk LQ45 Periode Agustus 2015-Januari 2016 di Bursa Efek Indonesia. Jurnal Ilmiah Ekonomi Global Masa Kini, 8(1), 41-45.

Romli, H., Ferita, R., \& Permata, L. T. (2016). Analisa Ratio Likuiditas, Solvabilitas dan Profitabilitas pada PT. Semen Baturaja Palembang Tahun 2012-2013. Jurnal Ilmiah Ekonomi Global Masa Kini, 7(1), 6369.

Saifullah E, Listiawati, Abay PM. Analisis Kinerja Keuangan Menggunakan Rasio Profitabilitas Pada
PT. XL AXIATA, Tbk dan PT Indosat OREDOO, Tbk Periode 2011 - 2016 Yang Terdaftar Di Bursa Efek Indonesia. J Banq Syar'I. 2016;4(1):15-32.

Sayadi, M. H. (2019). Evaluasi Kinerja Keuangan Sebelum dan Sesudah Akuisisi Menggunakan Profitabilitas. Jurnal Ilmiah Ekonomi Global Masa Kini, 10(1), 8-12.

Tanor MO, Sabijono H, Walandouw SK. Analisis Laporan Keuangan Dalam Mengukur Kinerja Keuangan Pada. J Ekon Dan Bisnis. 2015;3(3):639-649.

Trianto A. Analisis Laporan Keuangan Sebagai Alat Untuk Menilai Kinerja Keuangan Perusahaan Pada Pt . Bukit Asam (Persero) Tbk Tanjung Enim.J Ilm Ekon Glob Masa Kini. 2017;8(03):2-3.

Rabuisa WF, Runtu T, Wokas HRN. Analisis Laporan Keuangan Dalam Menilai Kinerja Keuangan Perusahaan Pada Bank Perkreditan Rakyat (Bpr) Dana Raya Manado. Going Concern J Ris Akunt. 2018;13(02):325-333. doi:10.32400/gc.13.02.19518.2018

Utari, R. J., Gustini, E., \& Tripermata, L. (2018). Pengaruh Profitabilitas, Financial Leverage, dan Dividend Payout Ratio Terhadapperataan Laba pada Perusahaan Manufaktur yang Terdaftardi Bei Tahun 2015. Jurnal Ilmiah Ekonomi Global Masa Kini, 8(2), 95-100. 